\title{
ANALISIS TINGKAT KEPUASAN MAHASISWA TERHADAP LAYANAN PENDIDIKAN PADA FAKULTAS EKONOMI DAN BISNIS UNIVERSITAS MATARAM
}

\author{
Junaidi Sagir ${ }^{1}$, Alamsyah AB $^{2}$, Emilia Septiani ${ }^{3}$ \\ ${ }^{1}$ Fakultas Ekonomi Dan Bisnis, Universitas Matara, junaidisagir@unram.ac.id \\ ${ }^{2}$ Fakultas Ekonomi Dan Bisnis, Universitas Mataram, alamsyah abubakar@yahoo.co.id \\ ${ }^{, 3}$ Fakultas Ekonomi Dan Bisnis, Universitas Mataram,emiliaseptiani@unram.ac.id

\begin{tabular}{|c|c|c|c|}
\hline $\begin{array}{l}\text { Dikirim tanggal } \\
\text { Revisi pertama tanggal }\end{array}$ & $\begin{array}{l}01 / 07 / 2021 \\
02 / 08 / 2021\end{array}$ & $\begin{array}{l}\text { Diterima tanggal } \\
\text { Tersedia online tanggal }\end{array}$ & $\begin{array}{l}13 / 08 / 2021 \\
10 / 09 / 2021\end{array}$ \\
\hline
\end{tabular}

\begin{abstract}
ABSTRAK
Tujuan penelitian ini adalah untuk melakukan pengukuran kepuasan dibandingkan dengan kinerja terhadap layanan pendidikan pada mahasiswa Fakultas Ekonomi Dan Bisnis Universitas Mataram, dengan model servqual dari Parasuraman et.al. yang terdiri dari 5 dimensi yaitu Tangible, Realibility, Responsiveness, Assurance dan Emphaty. Responden terdiri 135 orang mahasiswa yang dipilih secara purposive sampling dari 3 jurusan yang terbagi merata masing-masing 45 orang mahasiswa setiap jurusan. Data dianalisis dengan menggunakan Customer Satisfaction Index (CSI) atau Indek Kepuasan mahasiswa (IKM) dan Importance Performance Analysis (IPA). Dari Analisis tersebut ditemukan bahwa: rata-rata tingkat kepuasan layanan pendidikan mendapatkan skor 15,5 dengan IKM=72,48\% yang berada pada level "Memuaskan" dengan kualitas layanan berkategori "Baik". Tidak terdapat kesenjangan yang lebar antara tingkat kepuasan dengan tingkat kepentingan (harapan) pada ketiga jurusan yang diteliti. Untuk meningkatkan kepuasan mahasiswa, pimpinan perlu memperhatikan dimensi yang mendapatkan kepuasan terendah seperti pada dimensi tangible antara lain terdiri dari toilet, sarana ibadah, sarana oleh raga, penyediaan kantin, dan sarana pelengkap lainnya. Disamping itu perlu meningkatkan kepekaan dosen dan pegawai untuk memperlancar urusan mahasiswa terutama dalam proses pembimbingan skripsi.
\end{abstract}

Kata Kunci: Kualitas Layanan, Kepuasan Mahasiswa, Analisis Kinerja dan Kepentingan

\section{ABSTRACT}

The purpose of this study is to measure satisfaction compared to performance on educational services for students of the Faculty of Economics and Business, University of Mataram, using the servqual model from Parasuraman et.al. which consists of fives dimensions, namely Tangible, Realibility, Responsiveness, Assurance and Emphaty. Respondents consisted of 135 students who were selected by purposive sampling from 3 majors which were evenly divided 45 students for each department. Data were analyzed using the Customer Satisfaction Index (CSI) and the Importance Performance Analysis (IPA).

From the analysis it was found that: the average level of satisfaction in education services got a score of 15.5 with the IKM $=72.48 \%$ which was at the level of "Satisfactory" with service quality in the category of "Good". There is no wide gap between the level of satisfaction and the level of importance (expectation) in the three research majors.

To increase student satisfaction, leaders need to pay attention to the dimensions that get the lowest satisfaction, such as the tangible dimension, which includes toilets, religious facilities, physical facilities, provision of a canteen, and other complementary facilities. Besides, it is necessary to increase the sensitivity of lecturers and staff to facilitate student affairs, especially in the thesis guidance process.

Keywords:Service Quality, Students Satisfaction, Importance Performance Analysis 


\section{PENDAHULUAN}

Kesuksesan suatu organisasi dipengaruhi oleh banyak faktor dan salah satunya adalah dengan memberikan pelayanan terbaik bagi pelanggannya sehingga segala harapan mereka terpenuhi dan pada akhirnya akan menciptakan kepuasan (Motefakker: 2016, Manzoor:2013). Apabila pelanggan tidak puas, maka pada hari berikutnya mereka sudah bukan pelanggan kita lagi (Lele \& Sheth, 1991).

Kepuasan pelanggan adalah tingkat perasaan seseorang setelah membandingkan kinerja atau hasil yang dia rasakan dibandingkan dengan harapannya, Cravens (2006:218) mengungkapkan bahwa: "Untuk mencapai tingkat kepuasan yang tinggi, diperlukan adanya pemahaman tentang apa yang diinginkan konsumen, dengan mengembangkan komitmen setiap orang yang ada dalam lembaga untuk memenuhi kebutuhan konsumen". Dalam rangka memberikan kepuasan yang tinggi kepada konsumen atau pelanggan internal (mahasiswa) diperlukan pemahaman tentang apa yang diinginkan oleh kosumen itu sendiri.

\section{Penelitian Terdahulu}

Penelitian tentang kepuasan mahasiswa telah banyak dilakukan baik di Indonesia maupun di mancanegara, hal ini menunjukkan bahwa betapa pentingnya pelayanan terbaik bagi mahasiswa sebagai pelanggan utama suatu institusi pendidikan tinggi.

Yousapronpaiboon (2013) dalam studinya tentang: "Servqual:Measuring higher education service quality in Thailand" menemukan bahwa 5 dimensi dari instrumen Servqual dari 350 responden mahasiswa S1 Universitas Swasta di Thailand yang menjadi obyek penelitiannya, menunjukkan bahwa tidak satu dimensipun yang memuaskan sebagaimana yang diharapkan mahasiswa. Ketidak-puasan ini tercermin dari tingginya kesenjangan (gap) antara harapan dengan kenyataan. Adapan nilai kesenjangan tersebut adalah: -2.25 untuk dimensi realibiltas, $-2,72$ untuk dimensi daya tanggap, $-0,48$ untuk dimensi assurance, -0,248 untuk dimensi empati, dan -2,88 untuk dimensi tangible. Semakin lebar angka kesenjangannya, maka semakin tinggi ketidak-puasan pelayanan yang dirasakan mahasiswa. Dalam studi lainnya, Al-Alak \& Alnaser menguji hubungan antara kualitas layanan yang terdiri dari tangibility, responsiveness, realilibity, assurance dan empathy dengan kepuasan dari 301 orang mahasiswa di Fakultas Bisnis Universitas Yordan menemukan bahwa dimensi jaminan dan dan keandalan merupakan dua dimensi terpenting yang memiliki hubungan postip dan signifikan dengan kepuasan mahasiswa. Manzoor, (2013), dalam studinya berjudul “Measuring Student Satisfaction in Public and Private Universities in Pakistan” menemukan bahwa fasilitas yang disediakan untuk mahasiswa seperti fasilitas olah raga dan fasilitas transportasi mempunyai pengaruh yang signifikan terhadap kepuasan mahasiswa, sementara fasilitas asrama dan akomodasi tidak mempunyai pengaruh berarti untuk kepuasan mahasiswa. Startup (2015) dalam penelitiannya tentang Student satisfaction with academic service, menemukan bahwa, kepuasan yang paling tinggi didapatkan mahasiswa dari cara dosen melakukan presentasi dan menjelaskan materi perkuliahan. Tentunya ada beberapa hal yang menyebabkan mahasiswa tidak puas yaitu sempitnya waktu untuk berkonsultasi tentang materi pelajaran tersebut, dan terbatasnya kesempatan untuk melakukan kontak secara informal, baik dengan dosen maupun dengan tenaga kependidikan. Penelitian di Universitas dalam negeri juga tidak terlalu menunjukkan hasil yang berbeda. Hidayati, dkk (2014), misalnya dalam penelitiannya tentang "Analisis kepuasan mahasiswa Terhadap Kualitas Pelayanan Tenaga Administrasi di Fakultas Farmasi Universitas Ahmad Dahlan Yogyakarta" menemukan bahwa: seluruh elemen pelayanan yang diberikan oleh bagian administrasi 
belum ada yang mendekati ideal yaitu : nol (0). Hal ini ditandai dengan adanya gap antara harapan dan kenyataan. Tangible gapnya - 0,90, Keandalan gagya -0,90, Assurance gapnya $-0,90$, Empathy dengan gap $-1,10$ dan responsiveness dengan gap $-1,10$.

\section{KAJIAN PUSTAKA}

Memahami pelanggan merupakan aktivitas terpenting pada konsep pemasaran modern. Kegiatan pemasaran merupakan sekumpulan proses untuk penciptaan nilai, mengkomunikasikan nilai, dan penyerahan nilai tersebut kepada pelanggan, serta untuk mengelola hubungan pelanggan dengan cara yang bermanfaat bagi organisasi dan pemegang kepentingan (Kotler \& Keller, 2006, 6). Suatu organisasi dikatakan berorientasi pelanggan apabila konsep pemasaran yang menekankan pada pemenuhan kebutuhan dan keinginan pelanggan dilakukan dengan baik yang dapat memuaskan mereka (Assauri, 2012, 3). Untuk mengetahui tingkat kepuasan pelanggan, maka harus dilakukan berbagai upaya, dan salah satunya dengan melakukan pengukuran tingkat kepuasan yang mereka rasakan dari pelayanan yang diberikan.

Menurut Kotler (2008: 139) "Kepuasan (satisfaction) adalah perasaaan senang atau kecewa seseorang yang timbul karena membandingkan kinerja yang dipersepsikan produk (atau hasil) terhadap ekspektasi mereka". Sehingga dapat disimpulkan bahwa kepuasan adalah perasaan puas yang ditunjukkan oleh individu. Engel, et al (1990) dalam Tjiptono (2011: 433), mengungkapkan bahwa: Kepuasan pelanggan merupakan evaluasi pembeli, dimana alternative yang dipilih sekurang-kurangnya memberikan hasil sama atau melampaui harapan pelanggan. Sedangkan ketidakpuasan timbul apabila hasil diperoleh tidak memenuhi harapan pelanggan. Menurut Kotler dalam Tjiptono (2004: 146) "Kepuasan (satisfaction) pelanggan adalah tingkat perasaaan seseorang setelah membandingkan kinerja (atau hasil) yang dirasakan dibanding dengan harapan.

Lupiyoadi (2001: 158) menyatakan, dalam menentukan tingkat kepuasan pelanggan terdapat 5 dimensi atribut faktor utama yang harus diperhatikan penyedia jasa yaitu:

1. Kualitas produk. Pelanggan akan merasa puas bila hasil evaluasi mereka menunjukkan bahwa produk yang mereka gunakan berkualitas

2. Kualitas pelayanan, pelanggan akan merasa puas bila mereka mendapatkan pelayanan yang baik atau yang sesuai dengan yang diharapkan

3. Emosional. Pelanggan akan merasa bangga dan mendapatan keyakinan bahwa orang lain akan kagum terhadap dia bila menggunakan produk dengan merk tertentu yang cenderung mempunyai tingkat kepuasan yang lebih tinggi

4. Harga. Produk yang mempunyai kualitas yang sama tetapi menetapkan harga yang relatif murah akan memberikan nilai yang lebih tinggi kepada pelanggannya

5. Biaya. Pelanggan tidak perlu mengeluarkan biaya tambahan atau tidak perlu membuang waktu untuk mendapatkan suatu produk atau jasa cenderung puas terhadap produk atau jasa itu.

Pengukuran kepuasan pelanggan yang digunakan dalam penelitian ini ialah pengukuran kepuasan pelanggan yang bertujuan untuk mengetahui tingkat kepuasan pelanggan dengan menggunakan model SERVQUAL. Model SERVQUAL berasal dari penilaian kepuasan pelanggan terhadap lima dimensi utama kualitas pelayanan, diantaranya: "Reliabilitas (Reliability), daya tanggap (Responsiveness), jaminan (Assurance), empati (Empathy) dan bukti fisik (Tangible)" (Parasuraman, et al., 1988 dalam Tjiptono, 2011: 347). Penilaian kepuasan pelanggan menggunakan model SERVQUAL mencakup perhitungan perbedaan diantara nilai yang diberikan para 
pelanggan untuk setiap pasang pernyataan masing-masing dimensi kualitas pelayanan yang berkaitan dengan pelayanan yang diharapkan (expected service) dan pelayanan yang dipersepsikan (perceived service).

Kerangka konsep dalam penelitian ini dapat dilihat pada gambar 1 dibawah ini

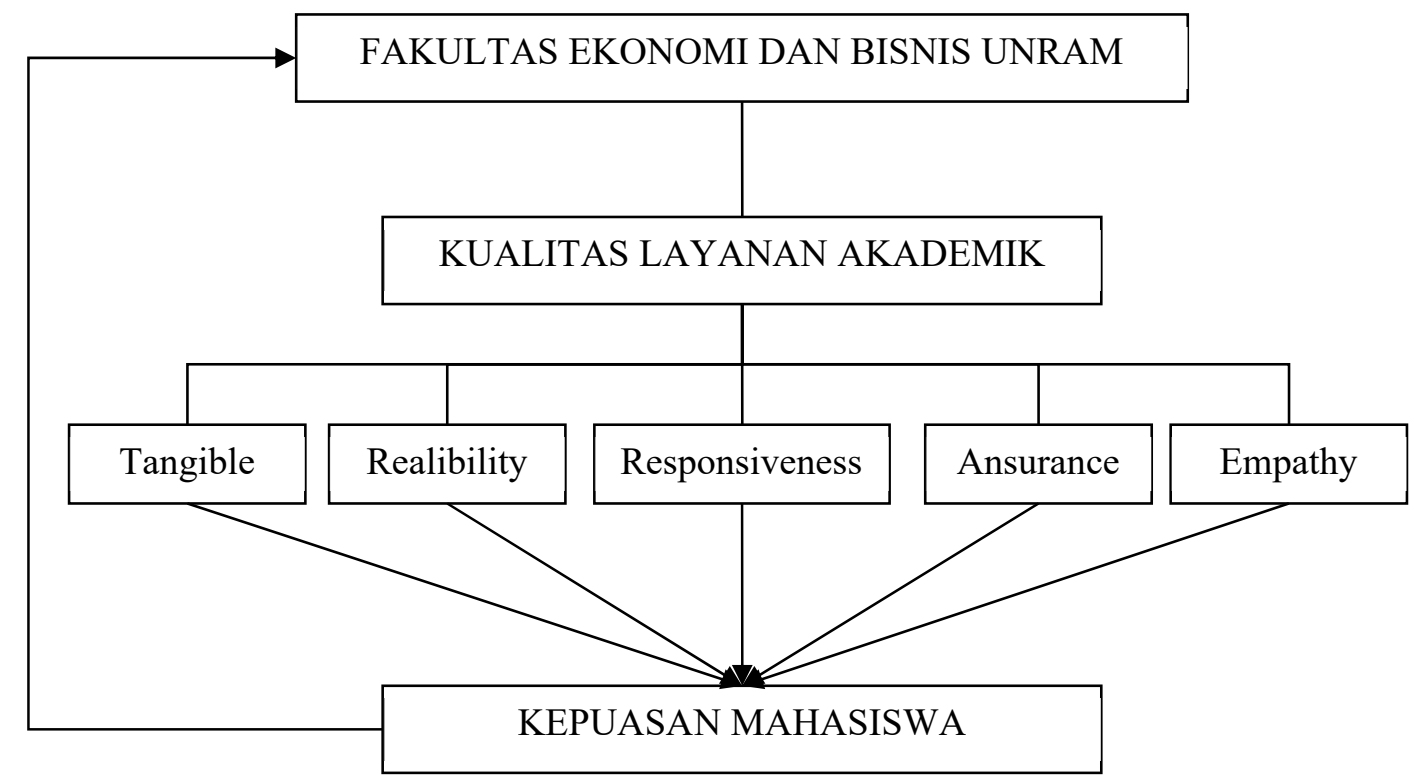

Gambar 1. Kerangka Konsep Penelitian

METODE PENELITIAN

Penelitian tentang Tingkat Kepuasan Mahasiswa Terhadap Pelayanan Pendidikan Pada Fakultas Ekonomi Dan Bisnis (FEB) Universitas Mataram ini merupakan penelitian deskriptif dengan menggunakan metode survei, adapun pengumpulan datanya dengan menggunakan angket. Menurut Arikunto (2002: 88), bahwa metode survei merupakan salah satu dokumen penelitian yang pada umumnya digunakan untuk mengumpulkan data yang luas dan banyak. Sedangkan Sigit (1999: 152), menyatakan bahwa penelitian survei biasanya digunakan dalam penelitian deskriptif menentukan dan melaporkan keadaan yang ada menurut kenyataannya, dengan mengukurnya. Penelitian ditujukan untuk mengungkapkan kondisi sesungguhnya tentang kepuasan mahasiswa FEB. terhadap layanan yang diterimanya.

\section{Populasi dan Sampel Penelitian}

Populasi dalam penelitian ini adalah semua mahasiswa Strata S1 pada Fakultas Ekonomi Dan Bisnis Universitas Mataram yang berjumlah 3.879 orang dari 3 jurusan yaitu: Jurusan manajemen 1698 orang, Jurusan Akuntansi 1.359 orang dan jurusan IESP $=822$ orang. Oleh karena jumlah populasinya diketahui, maka penentuan jumlah sampelnya dilakukan dengan menggunakan rumus dikemukakan oleh Yamane dalam Riduwan $(2010,65)$ sebagai berikut :

$$
n=\frac{\mathrm{N}}{N \cdot d^{2}+1}
$$

Dimana: $\mathbf{n}=$ Jumlah Sampel, $\mathbf{N}=$ Jumlah Populasi, $\mathbf{d}^{\mathbf{2}}=$ Maksimal Error. 
Dalam penelitian, ditetapkan maksimal error $10 \%(0,1)$, jadi dengan demikian, jumlah sampelnya, 98 (dibulatkan). Untuk mendapatkan hasil yang lebih baik, peneliti menetapkan sampel diatas jumlah sampel minimal yaitu 135 atau 138\%. Jumlah sampel ini diambil dari masing-masing jurusan sebesar 45 orang mahasiswa dengan metode accindental convinience sampling, artinya populasi yang dijadikan sampel adalah mahasiswa yang berhasil ditemui yang berhasil ditemui pada saat penelitian dini dilakukan.

\section{Instrumen dan Skala Pengukuran Instrumen Penelitian}

Arikunto (2006:163) menyebutkan bahwa metode penelitian adalah cara yang dugunakan oleh peneliti dalam mengumpulkan data penelitiannya, sedangkan instrument penelitian adalah alat atau fasilitas yang digunakan oleh peneliti dalam mengumpulkan data agar pekerjaannya lebih mudah, dan hasilnya lebih baik, dalam arti lebih cermat, lengkap, dan sistematis sehingga lebih mudah diolah. Pada penelitian ini instrumen yang digunakan adalah kuesioner dengan pedoman-pedoman tertentu sehingga bisa dilakukan baik secara offline maupun online. Sedangkan teknik pengumpulan datanya dengan cara observasi, wawancara dan dokumentas dalam hal ini mencatat perkembangan jumlah mahasiswa FEB Unram dari tahun ke tahun.

\section{Pengukuran Varibel Penelitian}

Jenis pernyataan yang dibuat pada kuesioner penelitian menggunakan skala Likert. Menurut (Sugiyono 2009) skala Likert berhubungan dengan pernyataan mengenai sikap / perilaku seseorang terhadap sesuatu, misalnya setuju dan tidak setuju, senang dan tidak senang, memuaskan dan tidak memuaskan, dan baik dan tidak baik. Variabel yang akan diukur dalam penelitian ini adalah tingkat kepuasan mahasiswa terhadap layanan pendidikan sebagaimana terlihat tabel 1 dibawah ini.

Tabel 1.

Kategori Penilain Kepuasan dan Kepentingan Mahasiswa

\begin{tabular}{cccccl}
\hline Kepuasan/Kinerja/Kenyataan/(Performance) & \multicolumn{3}{c}{$\begin{array}{c}\text { Kepentingan/Harapan } \\
\text { (Importance) }\end{array}$} \\
\hline No & \multicolumn{1}{c}{ Kriteria } & No & Kriteria \\
1 & TM & Tidak Memuaskan & 1 & TP & Tidak Penting \\
2 & KM & Kurang Memuaskan & 2 & KP & Kurang Penting \\
3 & CM & Cukup Memuaskan & 3 & CP & Cukup Penting \\
4 & M & Memuaskan & 4 & P & Penting \\
5 & SM & Sangat Memuaskan & 5 & SP & Sangat Penting \\
\hline
\end{tabular}

\section{Uji Instrumen Penelitian}

Uji instrumen penelitian terdiri dari uji validitas dan uji reliabilitas. Uji validitas dapat dilakukan dengan membandingkan nilai $r$ hitung (corrected item total correlation) dengan $r$ tabelnya.Apabila nilai $r$ hitung $>r$ tabel dan nilai $r$ positif, maka butir atau pertanyaan tersebut dikatakan valid, Ghozali (2005). Sedangkan uji reliabilitas adalah sesuatu instrumen cukup dapat dipercaya untuk digunakan sebagai alat pengumpul data karena instrumen tersebut sudah cukup baik. Menurut Ghozali (2005) Instrumen dapat dikatakan handal (reliable) bila mempunyai koefisien Cronbach alpha $>0,6$. Pengujian reliabilitas ini dilakukan dengan menggukan program SPSS 25.0 for windows (2020) 


\section{Alat Analisis Data}

Metode analisis data yang digunakandalam penelitian ini adalah adalah Importance Performance Analysis (IPA) atau Analisis Tingkat Kepentingan dan Kinerja Kepuasan Pelanggan (Supranto, 1997, 239). Berdasarkan hasil penilaian tingkat kepentingan dan hasil penilaian kinerja / penampilan maka akan dihasilkan suatu perhitungan mengenai tingkat kesesuaian antara tingkat kepentingan dan tingkat pelaksanaannya. Adapun Rumus yang digunakan adalah :

Dimana:

$$
T k i=\frac{X i}{Y i} \times 100 \%
$$

Tki $=$ tingkat kesesuaian harapan pelanggan

$\mathrm{Xi}=$ skor penilaian kinerja perusahaan

$\mathrm{Yi}=$ skor penilaian harapan pelanggan

Selanjutnya sumbu mendatar (X) akan diisi oleh skor tingkat pelaksanaan, sedangkan sumbu tegak (Y) akan diisi oleh skor tingkat kepentingan, sehingga rumusnya akan terlihat sbb:

$\bar{X} i=\frac{\sum X i}{n} \quad$ dimana $\mathrm{n}=$ jumlah responden

$\bar{Y} i=\frac{\sum Y i}{n}$

dimana $\mathrm{n}=$ jumlah responden

$\overline{\bar{X}} i=\frac{\sum \bar{X} i}{n}$

dimana $\mathrm{n}=$ jumlah variabel

$\overline{\bar{Y}} i=\frac{\sum \bar{Y} \mathrm{i}}{n} \quad$ dimana $\mathrm{n}=$ jumlah variabel

Keterangan:

$\bar{X}=$ Rata-rata dari kinerja aktual

$\overline{\bar{X}}=$ Rata-rata dari skor rata-rata kinerja aktual

$\bar{Y}=$ Rata-rata skor harapan mahasiswa

$\overline{\bar{Y}}=$ Rata-rata dari rata-rata skor harapan

Untuk selanjutnya tingkat unsur tersebut akan dijabarkan dan dibagi menjadi empat bagian (kuadran) kedalam diagram Kartesius (Supranto, 1997, 242), sebaimana terlihat pada gambar 2 dibawah ini

Gambar 2. Diagram Kartesius

\section{Kepentingan}

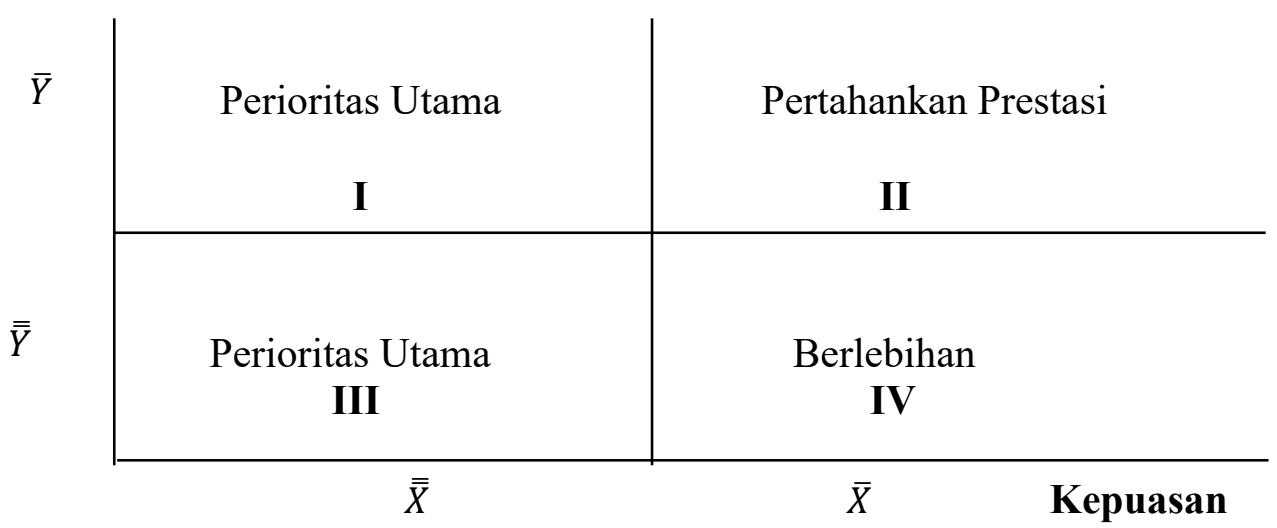




\section{Keterangan :}

Kuadran I : Ini adalah wilayah yang memuat faktor-faktor yang memiliki nilai harapan tinggi dari sudut pandang pelanggan tetapi pada kenyataannya kenyataan yang diperoleh masih sangat rendah. Variabel-variabel masuk dalam kuadran ini harus ditingkatkan dengan cara perusahaan tetap berkonsentrasi pada kuadran ini.

Kuadran II : Ini adalah wilayah yang memuat faktor-faktor yang memiliki nilai harapan tinggi dari sudut pandang pelanggan dan dalam kenyataan pelanggan, pelayanan yang didapat sudah sesuai dengan yang diharapkan. Variabel-variabel yang termasuk dalam kuadran ini harus tetap dipertahankan, karena variabel ini yang menjadikan produk tersebut memiliki keunggulan di mata pelanggan.

Kuadran III : Dalam wilayah ini, pelanggan tidak memiliki harapan tinggi terhadap faktor-faktor yang ada. Kenyataan atas kualitas pelayanan yang didapat pelanggan pun biasa saja atau tidak terlalu istimewa. Variabel-variabel yang termasuk dalam kuadran ini memiliki pengaruh kecil terhadap manfaat yang dirasakan oleh pelanggan.

Kuadran IV : Dalam wilayah ini, pelanggan tidak memiliki harapan tinggi terhadap faktor-faktor yang ada. Akan tetapi, dalam pelayanan yang diterima pelanggan, nilai kenyataannya tinggi, sehingga dirasakan terlalu berlebihan. Variabel-variabel yang termasuk dalam kuadran ini dapat dipertimbangkan untuk dikurangi, sehingga perusahaan dapat menghemat biaya.

Setelah itu, akan dianalisis berdasarkan Costumer Satisfaction Index (CSI) menurut Bhote dalam Widodo dan Sutopo (2018) Skor (S) adalah hasil perkalian ratarata kepuasan (P) dengan rata-rata kepentingan (I) dibagi dengan 5 kali rata-rata kepentingan atau:

$$
\text { CSI }=\frac{\text { S }}{\text { 5xI }} \text { x } 100
$$

Keterangan:

$\mathrm{S}=$ Skor yaitu hasil perkalian rata-rata Importance (I) dan rata-rata Performance (P)

$5=$ Nilai Maksimum pada Skala Pengukuran

$\mathrm{I}=$ Nilai dari Kolom Harapan

Apabila ditungkan dalam tabel dengan interval 20 dan jumlah kelas 5, maka kategori kualitas layanan akan terlihat seperti pada tabel 2 dibawah ini::

Tabel 2.

Kategori Kualitas Layanan

\begin{tabular}{cll}
\hline No & \multicolumn{1}{c}{ Nilai CSI /IKM } & \multicolumn{1}{c}{ Kualitas Layanan } \\
\hline 1 & $0 \%-19,99 \%$ & Tidak Baik \\
2 & $20 \%-39,99 \%$ & Kurang Baik \\
3 & $40 \%-59,99 \%$ & Cukup Baik \\
4 & $60 \%-79,99 \%$ & Baik \\
5 & $80 \%-100 \%$ & Sangat Baik \\
\hline
\end{tabular}




\section{HASIL DAN BAHASAN}

\section{Deskripsi Karakteristik Responden}

Responden berdasrkan jenis kelamin adalah , 67\% perempuan dan 33\% laki-laki, sedangkan asal daerahnya didminasi oleh mahasiswa dari pulau Lombok yaitu mencapai 79\% yang terdiri dari 26\% (Kota Mataram), 20\% (Lombok Timur), 15\% (Lombok Barat), 15\% ( Lombok Tengah) dan 3\% (Lombok Utara), sementara sisanya yang 21\% berasal dari daerah lainnya baik yang ada di NTB., maupun dari luar propinsi. Ada 3 suku yang mendominasi responden yaitu suku Sasak 63\%, suku Samawa 11\% dan suku Mbojo 9\%. Selain itu ada suku Bali dan suku Jawa. Pekerjaan yang paling dominan orang tua responden adalah wirausaha yaitu sebanyak 62 orang atau $46 \%$, selanjutnya diikuti oleh pekerjaan di pemerintahan yaitu yang terdiri dari PNS/TNI/Polri 41 orang atau 30\%. Setelah itu karyawan swasta sebanyak $19 \%$ dan yang paling sedikit adalah karyawan BUMN. yaitu cuma 1 orang atau kurang dari 14\%. Sementara yang lainnya terdiri dari gabungan Ibu Rumah Tangga, Buruh Tani tidak bekerja adalah 4\%. Hal ini terlihat pada tabel 4.4. dibawah ini:

Uang Kuliah atau lebih populer disebut UKT (Uang Kuliah Tunggal) yang dibayarkan mahasiswa didominasi oleh mahasiswa penerima Bidik Misi yaitu : 35 orang atau 26\% dari seluruh responden, selanjutnya diikuti oleh pembayar UKT grade 4 sebanyak 26 orang atau $19 \%$ dan yang paling sedikit adalah responden yang membayar UKT grade II yaitu 18 orang atau $13 \%$.

\section{Uji Validitas dan Reliabilitas}

Sebelum data diproses dan kuesioner diedarkan, telah dilakukan uji validitas dan realibiltas dengan melibatkan 45 orang responden dengan jumlah pertanyaan 70 item, masing-masing 35 item untuk varibel kepuasan (kinerja) dan 35 item untuk varibel kepentingan (harapan). Dari hasil olahan dengan menggunakan bantuan SPSS versi 25.0 (2020) diperoleh angka $r$-tabel $=0,2018$ baik untuk variabel kepuasan maupun untuk varibel kepentingan. Sementara hasil perhitungan (r-hitung) lebih besar dari r-tabel untuk semua item yang ditanyakan, sehingga seluruh item baik untuk variabel kepuasan maupun untuk variabel kepentingan dinyatakan valid.

Sementara uji reliabilitas dilakukan dengan menggunakan koefisien Cronbach Alpha. Menurut Ghozali (2005) Instrumen dapat dikatakan handal (reliable) bila mempunyai koefisien Cronbach alpha $>0,6$. Pengujian reliabilitas ini dilakukan dengan menggukan program SPSS versi 25.0 (2020). Hasil uji tersebut menunjukkan bahwa Cronbach's Alfa untuk kepuasan $=0,966$ dan Kepentingan $=0,988$ dengan demikian semua item instruemennya dinyatakan reliable.

\section{Analisis Kesenjangan Kepuasan dan Kepentingan Jurusan Manajemen}

Berdasarkan analisis kesenjangan antara kepuasan/kinerja/kenyatakaan yang didapatkan mahasiswa dengan kepentingan/harapan harapan pada jurusan manajemen yang didapatkan dari 45 orang responden, sebagaimana terlihat pada tabel 3. dibawah ini: 
Tabel 3.

Analisis Kesenjangan Pada Jurusan Manajemen

\begin{tabular}{|c|c|c|c|c|c|c|c|c|}
\hline \multirow{2}{*}{ No } & \multirow{2}{*}{ Item Pertanyaan } & \multirow{2}{*}{ Dimensi } & \multicolumn{2}{|c|}{ Rerata Kepuasan } & \multicolumn{2}{|c|}{$\begin{array}{c}\text { Rerata } \\
\text { Kepentingan }\end{array}$} & \multicolumn{2}{|c|}{$\begin{array}{c}\text { Kesenjangan } \\
\text { (Gap) }\end{array}$} \\
\hline & & & Item & Dimensi & Item & Dimensi & Item & Dimensi \\
\hline 1 & Ruang kuliah & & 3.48 & & 4.20 & & -0.72 & \\
\hline 2 & Alat bantu ajar & & 4.04 & & 4.33 & & -0.29 & \\
\hline 3 & Website & Tan-gible & 3.62 & & 4.24 & & -0.62 & \\
\hline 4 & Ruang pegawai & (sarana & 3.55 & & 4.22 & & -0.67 & \\
\hline 5 & Sarana utk mhs. & fisik) & 3.60 & 3.233 & 4.13 & 4.17 & -0.53 & -0.61 \\
\hline 6 & Sarana ibadah & & 3.75 & & 4.26 & & -0.51 & \\
\hline 7 & Sarana toilet & & 2.88 & & 3.80 & & -0.92 & \\
\hline 8 & Kehadiran dosen & & 3.75 & & 4.20 & & -0.45 & \\
\hline 9 & SAP/RPP & & 4.11 & & 4.26 & & -0.15 & \\
\hline 10 & Relevansi Mata Kuliah & & 3.91 & & 4.20 & & -0.29 & \\
\hline 11 & Obyektiftas Penilaian & Reali-bilty & 3.73 & 3.73 & 4.06 & 4.10 & -0.33 & -0.37 \\
\hline 12 & Dosen PA & (Kehandala & 3.91 & & 4.13 & & -0.22 & \\
\hline 13 & Kehandalan pegawai & $\mathrm{n})$ & 3.57 & & 3.97 & & -0.4 & \\
\hline 14 & Akurasi pelayanan & & 3.53 & & 4.02 & & -0.49 & -0.774 \\
\hline 15 & Kesiap-siagaan pegawai & & 3.35 & & 3.97 & & -0.62 & \\
\hline 16 & Mudah dihubungi & & 3.28 & & 3.91 & & -0.63 & \\
\hline 17 & Solusi permasalahan & Respon- & 3.37 & & 4.00 & & -0.63 & \\
\hline 18 & Kalender akademik & siveness & 4.28 & & 4.11 & & 0.17 & \\
\hline 19 & Mau mendengar keluhan & (Ketang- & 3.44 & 3.57 & 3.95 & 4.00 & -0.51 & -0.43 \\
\hline 20 & Cepat dan tepat & gapan) & 3.57 & & 4.11 & & -0.54 & \\
\hline 21 & Respons segera & & 3.46 & & 3.93 & & -0.47 & \\
\hline 22 & Kompetensi dosen & & 4.22 & & 4.35 & & -0.13 & \\
\hline 23 & Perlakuan yg adil & Assu- & 3.93 & & 4.22 & & -0.29 & \\
\hline 23 & Kesesuaian kurikulum & ransce & 3.86 & & 4.13 & & -0.27 & \\
\hline 25 & Cakap bekerja & (Keya- & 3.71 & 3.87 & 4.08 & 4.14 & -0.37 & -0.27 \\
\hline 26 & Ada SOP/POB & kinan/ & 3.93 & & 4.13 & & -0.2 & \\
\hline 27 & Sesuai prosedur & jaminan/ke & 3.86 & & 4.06 & & -0.2 & \\
\hline 28 & Adanya sangsi tegas & pastian & 3.75 & & 4.08 & & -0.33 & \\
\hline 29 & Jam kerja & & 3.71 & & 4.11 & & -0.4 & \\
\hline 30 & Kesedian membantu & & 3.68 & & 4.13 & & -0.45 & \\
\hline 31 & Berkomunikasi dg baik & & 3.62 & & 4.06 & & -0.44 & \\
\hline 32 & Monitoring dosen PA & Empa- & 3.62 & 3.67 & 4.08 & 4.1 & -0.46 & -0.43 \\
\hline 33 & Kesediaan membimbing & thy (Kepe- & 3.75 & & 4.02 & & -0.27 & \\
\hline 34 & Kepedulian pegawai & dulian) & 3.55 & & 4.15 & & -0.6 & \\
\hline \multirow[t]{2}{*}{35} & Pelayanan sesuai standar & & 3.77 & & 4.13 & & -0.36 & \\
\hline & Rata2 & & 3.69 & 3.69 & 4.11 & 4.11 & -0.42 & -0.42 \\
\hline
\end{tabular}

Sumber : Data Primer Diolah

Pada tabel 3. diatas terlihat bahwa rata-rata kepuasan mahasiswa jurusan manajemen terhadap pelayanan pendidikan yang diterimanya berada pada angka 3,69 atau pada kategori Memuaskan untuk semua dimensi, sementara kepentingan/harapan mereka pada pelayanan tersebut berada pada angka 4,11 yang berada pada kategori penting. Dengan demikian antara kepuasan dengan kepentingan tidak terdapat kesenjangan yang terlalu lebar yaitu hanya $-0,42$, yang apabila dihitung berdasarkan Indek Kepuasan Konsumen (IKM) atau Costumer Satisfaction Index (CSI), dengan rumus : perkalian rata-rata kepuasan (P) dengan rata-rata Kepentingan (I) dibagi dengan $5 \mathrm{xI}=$ $3,69 \times 4,11: 5 \times 4,11=15,17: 20,55 \times 100=73,82 \%$ atau kalau dibulatkan menjadi $\mathbf{7 4 \%}$, yang termasuk dalam kualitas layanan berkategori Baik. 
Dari tabel diatas juga terlihat bahwa kinerja yang paling memuaskan mahasiswa adalah pada dimensi Assurance dengan nilai 3,87 yaitu kemampuan jajaran Fakultas Ekonomi dan Bisnis (FEB) untuk menyediakan jasa yang dapat dipercaya dan memberikan rasa aman kepada mahasiswa seperti, kompetensi dosen, perlakuan yang adil, SOP/POB. yang dijalankan dengan baik, adanya sangsi yang tegas dan lainnya. Sedangkan pada sisi kepentingan, mahasiswa mengharapkan layanan yang paling tinggi pada dimensi Tangible dengan nilai 4,17 yaitu: harapan terhadap kualitas fasilitas fisik seperti, tersedianya ruang kuliah yang memadai dan nyaman, tersedianya areal parkir yang luas, tersedianya fasilitas-fasilitas penunjang yang yang memadai dan tersedianya alat bantu ajar yang mencukupi. Dengan demikian baik kepuasan/kinerja dan kepentingan/harapan berada pada interval $3.41-4.20$ yaitu pada ketagori memuaskan (M) dan penting (P). Apabila dihitung berdasarkan IKM/CSI) maka layanan pendidikan pada dimensi Assurance didapatkan angka $=3,87 \times 4,14: 5 \times 4,14=16,02: 20,70 \times 100=77 \%$, yang termasuk dalam kualitas pelayanan berkategori Baik..

Sementara untuk penilaian kepuasan per-item, terdapat 3 nilai tertinggi masing-masing pada item no. 18 tentang Pelaksanaan perkuliahan dan ujian selalu sesuai dengan kalender akademik dengan nilai 4,28 sangat memuaskan (SM), lalu pada item no. 22 tentang Kompetensi dosen dalam bidang yang diajarkannya dengan nilai 4,22 (SM), dan item no. 9 tentang metode pemberian kuliah oleh dosen yang selalu merujuk pada RPP/SAP. yang ada dengan nilai 4,11 , memuaskan (M)

Sedangkan yang masih menjadi hambatan dan membuat mahasiswa belyum merasa puas serta harus menjadi perhatian pimpinan baik ditingkat jurusan maupun fakultas adalah masing-masing pada item no. 7 tentang tersedianya toilet yang bersih dalam jumlah yang mencukupi hanya mendapatkan nilai 2.88 cukup memuaskan (CM), setelah itu pada item no. 16 tentang dosen dan pegawai mudah dihubungi baik langsung maupun melalui media komunikasi mendapatkan nilai 3,28 (CM) dan pada item no. 15 tentang Keberadaan/kesiap-siagaan pegawai dalam melayani kepentingan mahasiswa dengan nilai $3.35(\mathrm{CM})$

Apabila tingkat kepuasan dan kepentingan responden jurusan manajemen diaplikasikan dalam diagram Kartesisius, maka akan terlihat seperti pada gambar 3 dibawah ini.

Gambar 3. Diagram Kartesius Jurusan Manajemen

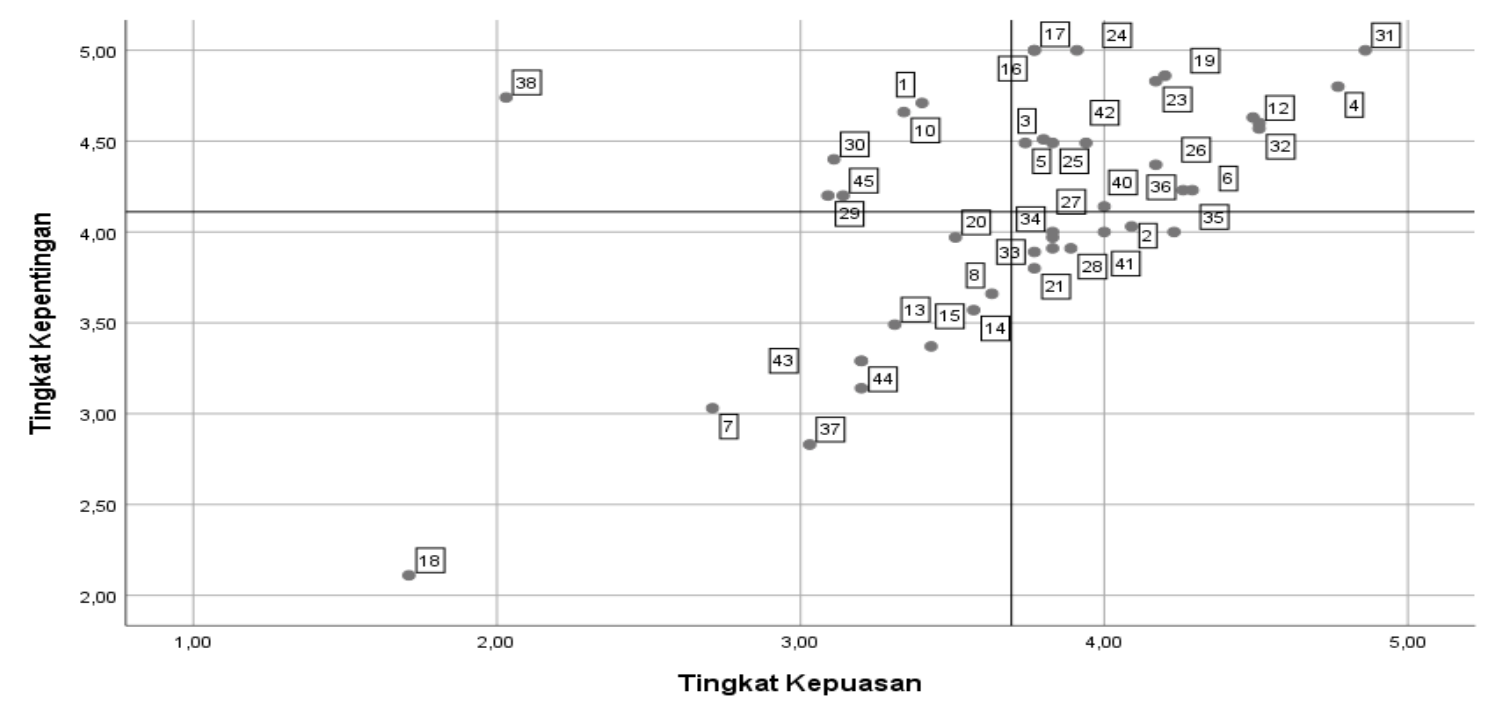

Pada gambar 3 terlihat bahwa bahwa rata-rata kepuasan responden (sumbu X) berada 
pada angka 3,69 dan tingkat kepentingan (sumbu Y) berada pada angka 4,11. Responden terbanyak yaitu 18 orang $(40 \%)$ berada pada kuadran II, artinya: mahasiswa mengharapkan kualitas layanan yang didapatkan tinggi dan pada kenyataannya juga kinerja jurusan manajemen dan FEB. bisa memenuhi harapan tersebut, sehingga prestasi seperti ini harus dipertahankan dan bila perlu ditingkatkan. Responden terbanyak berikutnya yaitu 11 orang (24\%) berada pada kuadran IV artinya, pelanggan tidak terlalu berharap untuk mendapatkan pelayanan yang berkualitas tinggi, akan tetapi pelayanan yang diterimanya melebihi dari harapan, sehingga dikategorikan berlebihan. Sementara responden yang paling sedikit yaitu 7 orang $(16 \%)$ berada pada kuadran I artinya mahasiswa mengharapkan kepuasan tinggi disini akan tetapi pada kenyataannya kinerja yang didapakn rendah, sehingga harus menjadi perioritas utama bagi jurusan dan FEB. Untuk diperbaiki.

Apabila dilihat berdasarkan tabel kelas kategori kepuasan, maka 18\% responden merasa sangat puas, $54 \%$ puas, $24 \%$ cukup puas dan masing-masing $2 \%$ kurang puas dan tidak puas terhadap layanan pendidikan yang diterimanya baik dari jurusan manajemen maupun dari FEB.

\section{Jurusan Akuntansi}

Berdasarkan analisis kesenjangan antara kepuasan/kinerja/kenyatakaan yang didapatkan mahasiswa dengan kepentingan/harapan harapan pada jurusan Akuntansi yang didapatkan dari 45 orang responden, dapat dipaparkan sebagaimana terlihat pada tabel 4 dibawah ini:

Tabel 4.

Analisis Kesenjangan Pada Jurusan Akuntansi

\begin{tabular}{|c|c|c|c|c|c|c|c|c|}
\hline \multirow[t]{2}{*}{ No } & \multirow[t]{2}{*}{ Item Pertanyaan } & \multirow[t]{2}{*}{ Dimensi } & \multicolumn{2}{|c|}{$\begin{array}{c}\text { Rerata } \\
\text { Kepuasan }\end{array}$} & \multicolumn{2}{|c|}{$\begin{array}{c}\text { Rerata } \\
\text { Kepentingan }\end{array}$} & \multicolumn{2}{|c|}{$\begin{array}{c}\text { Kesenjangan } \\
\text { (Gap) }\end{array}$} \\
\hline & & & Item & Dimensi & Item & Dimensi & Item & Dimensi \\
\hline 1 & Ruang kuliah & & 3.73 & & 4.35 & & -0.62 & \\
\hline 2 & Alat bantu ajar & & 4.13 & & 4.53 & & -0.4 & \\
\hline 3 & Website & Tan-gible & 3.57 & & 4.24 & & -0.67 & \\
\hline 4 & Ruang pegawai & (sarana & 3.68 & 3.56 & 4.28 & 4.21 & -0.6 & -0.65 \\
\hline 5 & Sarana utk mhs. & fisik) & 3.51 & & 4.08 & & -0.57 & \\
\hline 6 & Sarana ibadah & & 3.42 & & 4.13 & & -0.71 & \\
\hline 7 & Sarana toilet & & 2.93 & & 3.88 & & -0.95 & \\
\hline 8 & Kehadiran dosen & & 3.91 & & 4.24 & & -0.33 & \\
\hline 9 & SAP/RPP & Reali-bilty & 4.08 & & 4.28 & & -0.2 & \\
\hline 10 & Relevansi Mata Kuliah & (Kehandal & 4.00 & & 4.44 & & -0.44 & \\
\hline 11 & Obyektiftas Penilaian & an) & 3.84 & 3.78 & 4.31 & 4.26 & -0.47 & -0.48 \\
\hline 12 & Dosen PA & & 4.00 & & 4.33 & & -0.33 & \\
\hline 13 & Kehandalan pegawai & & 3.48 & & 4.15 & & -0.67 & \\
\hline 14 & Akurasi pelayanan & & 3.57 & & 4.17 & & -0.6 & \\
\hline 15 & Kesiap-siagaan pegawai & & 3.37 & & 4.15 & & -0.8 & \\
\hline 16 & Mudah dihubungi & & 3.28 & & 4.00 & & -0.72 & \\
\hline 17 & Solusi permasalahan & Respon- & 3.46 & & 4.15 & & -0.69 & \\
\hline 18 & Kalender akademik & siveness & 4.28 & 3.55 & 4.37 & 4.17 & -0.09 & -0.62 \\
\hline 19 & Mau mendengar keluhan & (Ketang- & 3.35 & & 4.17 & & -0.82 & \\
\hline 20 & Cepat dan tepat & gapan) & 3.46 & & 4.24 & & -0.78 & \\
\hline 21 & Respons segera & & 3.48 & & 4.08 & & -0.6 & \\
\hline 22 & Kompetensi dosen & Assu- & 4.31 & & 4.46 & & -0.15 & \\
\hline 23 & Perlakuan yg adil & ransce & 4.02 & & 4.26 & & -0.24 & \\
\hline 23 & Kesesuaian kurikulum & (Keya- & 3.86 & & 4.22 & & -0.36 & \\
\hline 25 & Cakap bekerja & kinan/ & 3.86 & 3.88 & 4.20 & 4.24 & -0.34 & -0.36 \\
\hline
\end{tabular}




\begin{tabular}{|c|c|c|c|c|c|c|c|c|}
\hline \multirow{2}{*}{ No } & \multirow{2}{*}{ Item Pertanyaan } & \multirow{2}{*}{ Dimensi } & \multicolumn{2}{|c|}{$\begin{array}{c}\text { Rerata } \\
\text { Kepuasan }\end{array}$} & \multicolumn{2}{|c|}{$\begin{array}{c}\text { Rerata } \\
\text { Kepentingan } \\
\end{array}$} & \multicolumn{2}{|c|}{$\begin{array}{c}\text { Kesenjangan } \\
\text { (Gap) }\end{array}$} \\
\hline & & & Item & Dimensi & Item & Dimensi & Item & Dimensi \\
\hline 26 & Ada SOP/POB & \multirow{4}{*}{$\begin{array}{l}\text { jaminan/ } \\
\text { kepastian) }\end{array}$} & 3.73 & & 4.20 & & -0.47 & \\
\hline 27 & Sesuai prosedur & & 3.73 & & 4.20 & & -0.47 & \\
\hline 28 & Adanya sangsi tegas & & 3.84 & & 4.26 & & -0.42 & \\
\hline 29 & Jam kerja & & 3.57 & & 4.17 & & -0.46 & \\
\hline 30 & Kesedian membantu & \multirow{6}{*}{$\begin{array}{c}\text { Empa- } \\
\text { thy (Kepe- } \\
\text { dulian) }\end{array}$} & 3.73 & & 4.24 & & -0.51 & \\
\hline 31 & Berkomunikasi dg baik & & 3.77 & & 4.22 & & -0.45 & \\
\hline 32 & Monitoring dosen PA & & 3.68 & 3.66 & 4.06 & 4.18 & -0.38 & -0.52 \\
\hline 33 & Kesediaan membimbing & & 3.68 & & 4.22 & & -0.54 & \\
\hline 34 & Kepedulian pegawai & & 3.46 & & 4.20 & & -0.74 & \\
\hline 35 & Pelayanan sesuai standar & & 3.64 & & 4.15 & & -0.51 & \\
\hline & Rata-rata & & 3.70 & 3.70 & 4.22 & 4.22 & -0.52 & -0.52 \\
\hline
\end{tabular}

Sumber : Data Primer, diolah

Pada tabel 4 diatas terlihat bahwa rata-rata kepuasan mahasiswa jurusan manajemen terhadap pelayanan pendidikan yang diterimanya berada pada angka 3,70 atau pada kategori Memuaskan (M) untuk semua dimensi, sementara kepentingan/harapan mereka pada pelayanan tersebut berada pada angka 4,22 yang berada pada kategori Sangat Penting (SP). Walaupun demikian antara kepuasan dengan kepentingan/harapan tidak terdapat kesenjangan yang terlalu lebar yaitu hanya $-0,52$. Apabila dihitung berdasarkan IKM/CSI, yaitu: $(3,70 \times 422):(5 \times 4,22) \times 100 \%=$ $15,61: 21,1 \times 100 \%=73,98$ atau kalau dibulatkan menjadi $\mathbf{7 4 \%}$. Dengan demikian jurusan Akuntansi sama dengan jurusan Manajemen yang termasuk dalam kualitas layanan berkategori Baik.

Dari tabel diatas juga terlihat bahwa kinerja yang paling memuaskan mahasiswa adalah pada dimensi Assurance dengan nilai 3,70 (Memuaskan) yaitu keyakinan akan kemampuan jajaran jurusan Akuntansi dan FEB. dalam menyediakan jasa yang dapat dipercaya dan memberikan rasa aman kepada mahasiswa. Dimensi ini sama dengan yang ada pada jurusan manajemen. Sedangkan pada sisi kepentingan (harapan) mahasiswa memberikan penilaian paling tinggi pada dimensi Realibilty dengan nilai 4,26 (Sangat Penting), artinya harapan terhadap layanan pendidikan yang diberikan oleh jurusan Akuntansi dan FEB seperti, kehadiran dosen yang tepat waktu, dosen yang selalu merujuk pada RPP/SAP dalam mengajar, kemampuan dosen dalam menjelaskan, kinerja pegawai yang dapat diandalkan sangat tinggi. Apabila kepuasan mahasiswa ini dihitung dengan Indek Kepuasan Mahasiswa (IKM) maka akan terlihat $=(3,70 \times 4,26):(5 \times 4,26) \times 100 \%=$ 15,76:21,3x $100 \%=\mathbf{7 4 \%}$, yaitu termasuk kualitas layanan berkategori Baik.

Sementara untuk penilaian kepuasan per-item, terdapat 3 nilai tertinggi masingmasing pada item no. 22 tentang kompetensi dosen pada mata kuliah yang diajarkannya dengan nilai 4,31 sangat memuaskan (SM), lalu pada item no. 18 tentang Pelaksanaan perkuliahan dan ujian selalu sesuai dengan kalender akademik dengan nilai 4,28 sangat memuaskan (SM), dan item no. 2 tentang tersedianya alat bantu ajar yang memadai dengan 4,13, memuaskan (M)

Sedangkan yang masih menjadi hambatan dan membuat mahasiswa belum puas serta harus menjadi perhatian pimpinan untuk ditingkatkan kualitasnya adalah masing-masing pada item no. 7 tentang tersedianya toilet yang bersih dalam jumlah yang mencukupi hanya mendapatkan nilai 2.93 cukup memuaskan (CM), setelah itu pada item no. 16 tentang dosen dan pegawai mudah dihubungi baik langsung maupun melalui media komunikasi mendapatkan nilai 3,28 (CM) dan pada item no. 15 tentang Keberadaan/kesiap-siagaan pegawai dalam melayani kepentingan mahasiswa dengan 
nilai 3.35 (CM). Keadaan seperti ini sama persis dengan yang ada di jurusan Manajemen Apabila tingkat kepuasan dan kepentingan mahasiswa jurusan Akuntansi diaplikasikan dalam bentuk diagram Kartesisius, maka akan terlihat seperti pada gambar 4 dibawah ini

Gambar 4. Diagram Kartesius Jurusan Akuntansi

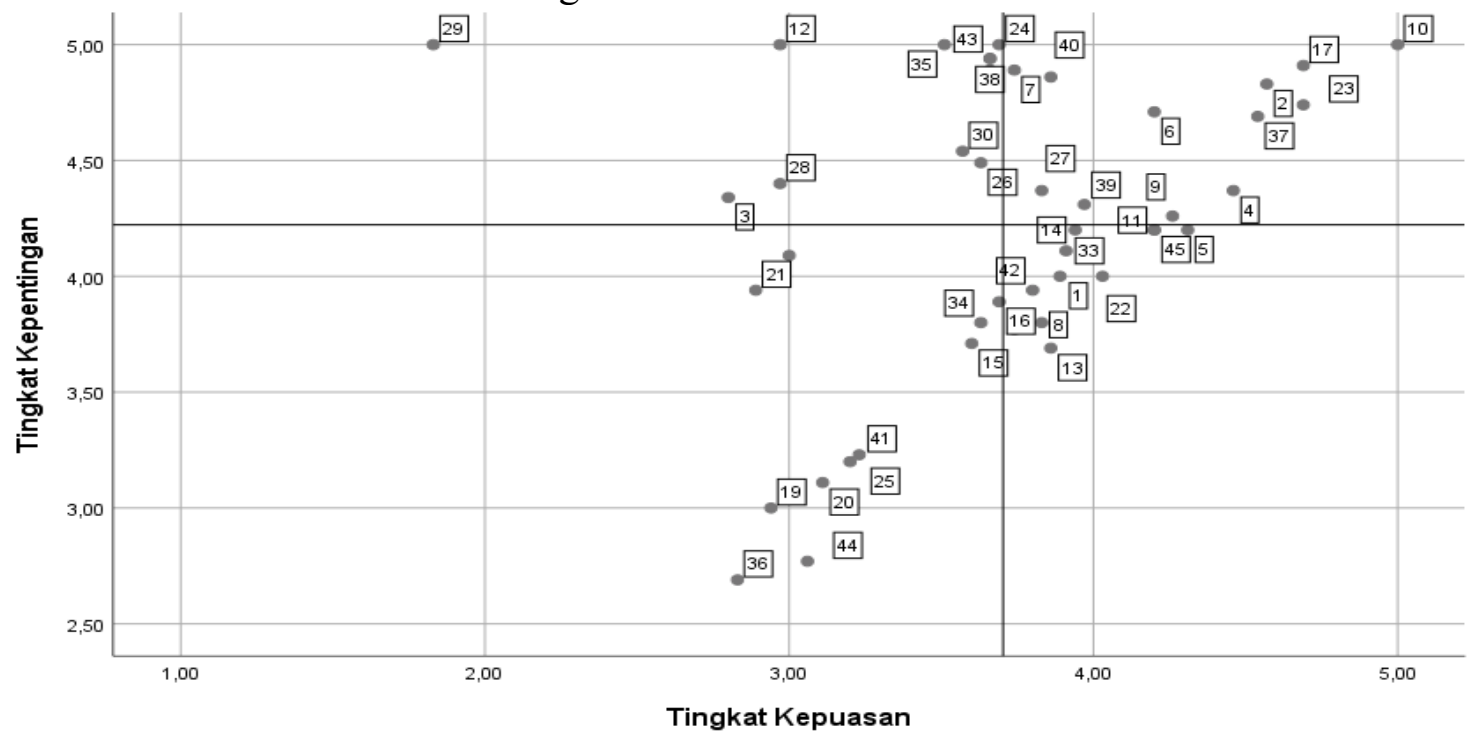

Pada gambar terlihat bahwa rata-rata kepuasan mahasiswa jurusan Akuntansi pada Axis $X=3,70$. Sementara responden terbanyak yaitu 16 orang (36\%) berada pada kuadran II, artinya: mahasiswa mengharapkan kualitas layanan yang didapatkan tinggi dan pada kenyataannya juga kinerja jurusan dan fakultas dapat memenuhi harapan mahasiswa tersebut, sehingga prestasi seperti ini harus dipertahankan dan bila perlu ditingkatkan. Responden terbanyak berikutnya yaitu 11 orang (24\%) berada pada kuadran IV artinya, mahasiswa tidak berharap terlalu tinggi untuk mendapatkan pelayanan yang berkualitas, akan tetapi pada kenyataanya pelayanan yang diterimanya melebihi dari harapan, sehingga dikategorikan berlebihan. Sementara peringkat responden berikutnya berada pada kuadran I dan III dengan jumlah yang sama yaitu masing-masing 9 orang atau 20\%. Apabila dilihat dari kategori kualitas layanan bahwa 18\% responden merasa Sangat Memuaskan (SM), 56\% Memuaskan (M), 24\% Cukup Memuaskan (CM) dan 2\% Kurang Memuaskan (KM) dan tidak terdapat kategori Tidak Memuaskan (TM)..

\section{Jurusan Ilmu Ekonomi Studi Pembangunan (IESP)}

Berdasarkan analisis kesenjangan antara kepuasan/kinerja/kenyatakaan yang didapatkan mahasiswa dengan kepentingan/harapan harapan pada jurusan Ilmu Ekonomi Studi Pembangunan (IESP) yang didapatkan dari 45 orang responden, dapat dipaparkan sebagaimana terlihat pada tabel 5 dibawah ini: 
Tabel 5.

Analisis Kesenjangan Pada Jurusan IESP

\begin{tabular}{|c|c|c|c|c|c|c|c|c|}
\hline \multirow[t]{2}{*}{ No } & \multirow[t]{2}{*}{ Item Pertanyaan } & \multirow[t]{2}{*}{ Dimensi } & \multicolumn{2}{|c|}{$\begin{array}{c}\text { Rerata } \\
\text { Kepuasan }\end{array}$} & \multicolumn{2}{|c|}{$\begin{array}{c}\text { Rerata } \\
\text { Kepentingan }\end{array}$} & \multicolumn{2}{|c|}{$\begin{array}{c}\text { Kesenjangan } \\
\text { (Gap) }\end{array}$} \\
\hline & & & Item & Dimensi & Item & Dimensi & Item & Dimensi \\
\hline 1 & Ruang kuliah & \multirow{7}{*}{$\begin{array}{c}\text { Tan-gible } \\
\text { (sarana fisik) }\end{array}$} & 3.33 & \multirow{7}{*}{3.23} & 4.33 & & -1.00 & \multirow{7}{*}{-0.93} \\
\hline 2 & Alat bantu ajar & & 3.86 & & 4.33 & & -0.47 & \\
\hline 3 & Website & & 3.08 & & 4.15 & 416 & -1.07 & \\
\hline 4 & Ruang pegawai & & 3.40 & & 4.06 & 4.10 & -0.66 & \\
\hline 5 & Sarana utk mhs. & & 3.13 & & 4.11 & & -0.98 & \\
\hline 6 & Sarana ibadah & & 3.35 & & 4.26 & & -0.91 & \\
\hline 7 & Sarana toilet & & 2.48 & & 3.93 & & -1.45 & \\
\hline 8 & Kehadiran dosen & \multirow{8}{*}{$\begin{array}{c}\text { Reali-bilty } \\
\text { (Kehandalan } \\
\text { ) }\end{array}$} & 3.60 & \multirow{8}{*}{3.55} & 4.53 & & -0.93 & \multirow{8}{*}{-0.77} \\
\hline 9 & SAP/RPP & & 3.86 & & 4.28 & & -0.42 & \\
\hline 10 & Relevansi Mata Kuliah & & 3.80 & & 4.37 & 4.32 & -0.57 & \\
\hline 11 & Obyektiftas Penilaian & & 3.48 & & 4.40 & & -0.92 & \\
\hline 12 & Dosen PA & & 3.71 & & 4.46 & & -0.75 & \\
\hline 13 & Kehandalan pegawai & & 3.35 & & 4.24 & & -0.89 & \\
\hline 14 & Akurasi pelayanan & & 3.40 & & 4.17 & & -0.77 & \\
\hline 15 & Kesiap-siagaan pegawai & & 3.17 & & 4.11 & & -0.94 & \\
\hline 16 & Mudah dihubungi & \multirow{6}{*}{$\begin{array}{c}\text { Respon- } \\
\text { siveness } \\
\text { (Ketang- } \\
\text { gapan) }\end{array}$} & 3.17 & \multirow{6}{*}{3.36} & 4.17 & \multirow{6}{*}{4.18} & -1.00 & \multirow{6}{*}{-0.82} \\
\hline 17 & Solusi permasalahan & & 3.42 & & 4.24 & & -0.82 & \\
\hline 18 & Kalender akademik & & 4.06 & & 4.22 & & -0.16 & \\
\hline 19 & Mau mendengar keluhan & & 3.06 & & 4.11 & & -1.05 & \\
\hline 20 & Cepat dan tepat & & 3.28 & & 4.26 & & -0.98 & \\
\hline 21 & Respons segera & & 3.17 & & 4.06 & & -0.89 & \\
\hline 22 & Kompetensi dosen & \multirow{8}{*}{$\begin{array}{c}\text { Assu-ransce } \\
\text { (Keya-kinan/ } \\
\text { jaminan/ } \\
\text { kepastian) }\end{array}$} & 4.06 & \multirow{8}{*}{3.67} & 4.42 & & -0.36 & \multirow{8}{*}{-0.54} \\
\hline 23 & Perlakuan yg adil & & 3.77 & & 4.31 & & -0.54 & \\
\hline 23 & Kesesuaian kurikulum & & 3.64 & & 4.26 & 421 & -0.62 & \\
\hline 25 & Cakap bekerja & & 3.57 & & 4.13 & T.21 & -0.56 & \\
\hline 26 & Ada SOP/POB & & 3.53 & & 4.17 & & -0.64 & \\
\hline 27 & Sesuai prosedur & & 3.48 & & 4.11 & & -0.63 & \\
\hline 28 & Adanya sangsi tegas & & 3.75 & & 4.22 & & -0.47 & \\
\hline 29 & Jam kerja & & 3.57 & & 4.08 & & -0.51 & \\
\hline 30 & Kesedian membantu & \multirow{6}{*}{$\begin{array}{c}\text { Empa- } \\
\text { thy (Kepe- } \\
\text { dulian) }\end{array}$} & 3.40 & \multirow{6}{*}{3.51} & 4.22 & & -0.82 & \multirow{6}{*}{-0.68} \\
\hline 31 & Berkomunikasi dg baik & & 3.57 & & 4.11 & & -0.54 & \\
\hline 32 & Monitoring dosen PA & & 3.68 & & 4.13 & 4.19 & -0.45 & \\
\hline 33 & Kesediaan membimbing & & 3.35 & & 4.26 & & -0.91 & \\
\hline 34 & Kepedulian pegawai & & 3.51 & & 4.31 & & -0.8 & \\
\hline 35 & Pelayanan sesuai standar & & 3.57 & & 4.11 & & -0.54 & \\
\hline & Rata-rata & & 3.47 & 3.47 & 4.22 & 4.22 & -0.75 & -0.75 \\
\hline
\end{tabular}

Sumber : Data Primer Diolah

Pada tabel 5. diatas terlihat bahwa rata-rata kepuasan mahasiswa jurusan IESP. $=3,47$ atau pada kategori Memuaskan (M) untuk semua dimensi, sementara kepentingan/harapan mereka atas layanan tersebut berada pada angka 4,22 yang berada pada kategori Sangat Penting (SP). Dengan demikian antara kepuasan dengan kepentingan terdapat kesenjangan yang relatif lebih lebar apabila dibandingan dengan 
kesenjangan pada jurusan Manajemen dan jurusan Akuntansi yaitu -0,75. Apabila diaplikasikan kedalam Indek Kepuasan mahasiswa (KKM) maka $=(3,47 \times 4,22) /(5 \times 4,22)=14,64 / 21,10 \times 100 \%=69 \%$. yang masih termasuk kualitas layanan berkategori Baik.

Dari tabel diatas juga terlihat bahwa kinerja yang paling memuaskan mahasiswa adalah pada dimensi Assurance dengan nilai 3,67 yaitu keyakinan akan kemampuan jajaran jurusan IESP dan FEB. dalam menyediakan jasa yang dapat dipercaya dan memberikan rasa aman kepada mahasiswa. Sedangkan pada sisi kepentingan (harapan) mahasiswa memberikan penilaian paling tinggi pada dimensi Realibilty dengan nilai 4,32 artinya harapan terhadap kehandalan pelayanan yang diberikan oleh jurusan dan Fakultas seperti, kehadiran dosen yang tepat waktu, dosen yang selalu merujuk pada RPP/SAP dalam mengajar, kemampuan dosen dalam menjelaskan, kinerja pegawai yang dapat diandalkan sangat penting. Dengan demikian kategori pada kepuasan/kinerja di jurusan IESP berada pada interval 3.41 - 4.20 yaitu pada ketagori memuaskan (M) dan ini sama dengan jurusan Manajemen dan Akuntansi. Sedangkan untuk kepentingan / harapan, jurusan IESP berada pada interval 4.21 - 5.00 yaitu kategori Sangat Penting (SP)

Sementara untuk penilaian kepuasan per-item, terdapat 2 nilai tertinggi yang sama yaitu pada item no. 22 tentang kompetensi dosen pada mata kuliah yang diajarkannya dengan nilai 4,06, memuaskan (M), dan item no. 18 tentang Pelaksanaan perkuliahan dan ujian selalu sesuai dengan kalender akademik dengan nilai yang sama yaitu 4,06, memuaskan (M). Sedangkan nilai tinggi berikut ada pada item no. 2 tentang tersedianya alat bantu ajar yang memadai dengan 3,86 memuaskan (M)

Sedangkan yang masih menjadi hambatan dan membuat mahasiswa belum puas serta harus menjadi perhatian pimpinan baik di jurusan maupun di tingkat Fakultas adalah masing-masing pada item no. 7 tentang tersedianya toilet yang bersih dalam jumlah yang mencukupi hanya mendapatkan nilai 2,48 cukup memuaskan (CM), setelah itu pada item no. 19 tentang dosen dan pegawai yang mau mendengarkan keluhan mendapatkan nilai 3,06 (CM) dan pada item no. 15 tentang Keberadaan/kesiap-siagaan pegawai dalam melayani kepentingan mahasiswa dengan nilai 3,17 (CM). Keadaan seperti ini sama persis dengan yang ada di jurusan Manajemen dan jurusan Akuntansi.

Apabila tingkat kepuasan dan kepentingan responden jurusan IESP diaplikasikan dalam bentuk diagram Kartesisius, maka akan terlihat seperti pada gambar 5 dibawah ini

Gambar 5. Diagram Kartesius Jurusan IESP

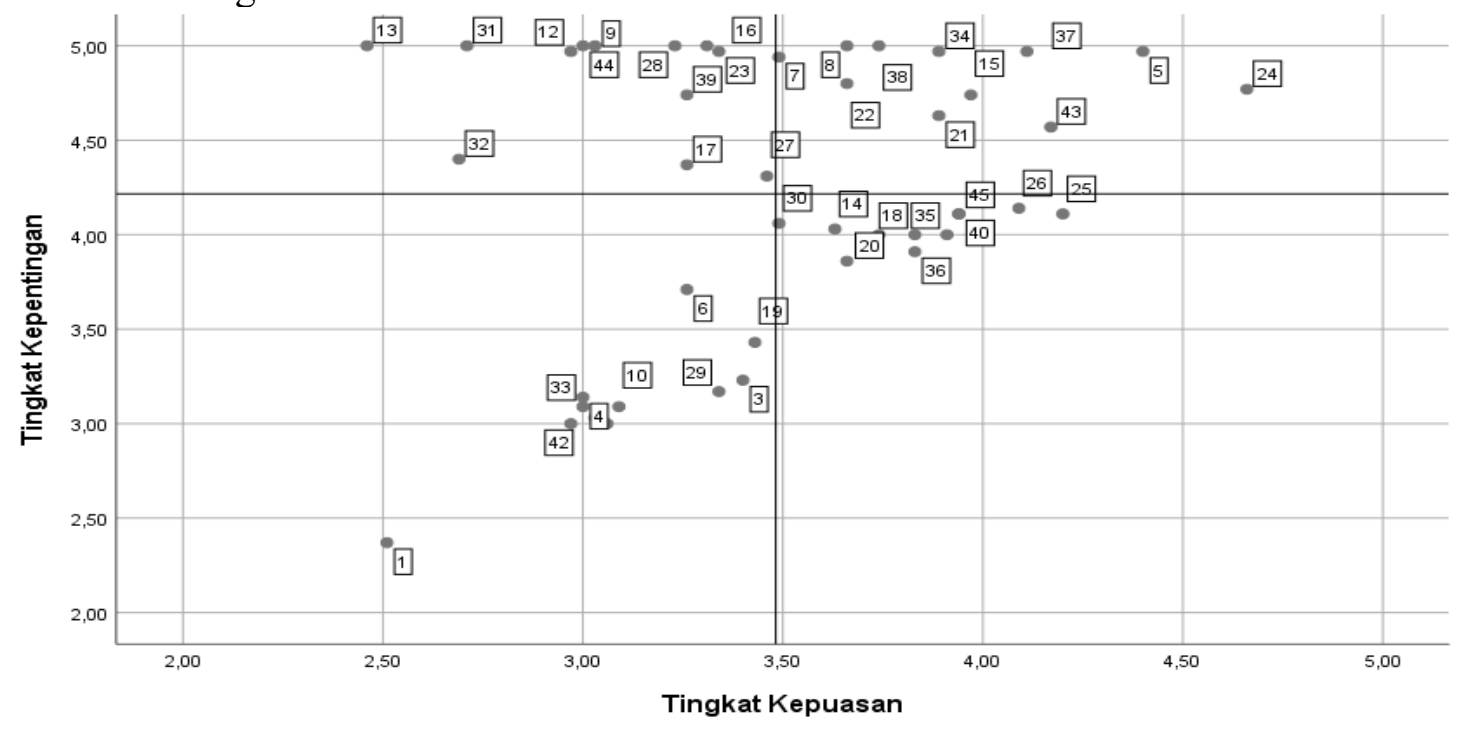


Pada gambar 3 diatas diketahui bahwa rata-rata tingkat kepuasan mahasiswa berada pada angka 3,47 (axis X) dan rata-rata kepentingan= 4,22 (axis Y). Apabila dilihat secara keselurusan didapati bahwa: responden terbanyak yaitu 16 orang $(36 \%)$ berada pada kuadran II, artinya: mahasiswa mengharapkan kualitas layanan yang didapatkan tinggi dan pada kenyataannya juga kinerja jurusan dan fakultas pada dimenensi ini dapat memenuhi harapan mahasiswa, sehingga prestasi seperti ini harus dipertahankan dan bila perlu ditingkatkan.

Responden terbanyak berikutnya yaitu 11 orang (24\%) berada pada kuadran I yaitu: harapan mahasiswa untuk memperoleh layanan yang baik sangat tinggi, akan tetapi pada kenyataan kinerja yang ditunjukkan oleh jurusan dan Fakultas, masih rendah, sehingga menjadi perioritas utama untuk dibenahi. Sedangkan pada kuadran III dan IV dipilih oleh 9 orang responden atau masing-masing $20 \%$

Apabila dilihat berdasarkan interval kelas kategori kepuasan layanan maka 4\% responden merasa sangat puas, $49 \%$ puas, $42 \%$ cukup puas dan $4 \%$ kurang puas, sementara untuk kategori tidak puas tidak ada baik pada kinerja maupun harapan.

\section{Fakultas Ekonomi Dan Bisnis Universitas Mataram}

Berdasarkan analisis kesenjangan antara kepuasan/kinerja/kenyataan yang dirasakan mahasiswa dengan kepentingan/harapan dari 3 jurusan di FEB. Unram tidak terdapat perbedaan yang signifikan dari ketiga jurusan tersebut. Jurusan Akuntansi merasakan kepuasan yang paling tinggi dengan nilai 3,70, stelah itu jurusan Manajemen dengan nilai 3,69 dan yang paling rendah adalah jurusan IESP. Dilain pihak kepentingan/harapan dari jurusan dan FEB yang didambakan oleh mahasiswa paling tinggi diberikan oleh jurusan Akuntansi dan IESP dengan nilai 4,22 dan harapan terendah oleh jurusan Manajemen dengan nilai 4,11. Untuk lebih jelasnya dapat dilihat pada tabel 6 dibawah ini

Tabel 6.

Analisis Kesenjangan Pada Fakultas Ekonomi Dan Bisnis

\begin{tabular}{lccccccccc}
\hline \multirow{2}{*}{ Dimensi } & \multicolumn{2}{c}{$\begin{array}{c}\text { Jurusan } \\
\text { Manajemen }\end{array}$} & \multicolumn{2}{c}{$\begin{array}{c}\text { Jurusan } \\
\text { Akuntansi }\end{array}$} & \multicolumn{2}{c}{ Jurusan } & \multicolumn{3}{c}{ ESP } \\
\cline { 2 - 11 } & $\overline{\boldsymbol{X}}$ & $\overline{\boldsymbol{Y}}$ & $\overline{\boldsymbol{X}}$ & $\overline{\boldsymbol{Y}}$ & $\overline{\boldsymbol{X}}$ & $\overline{\boldsymbol{Y}}$ & $\overline{\boldsymbol{X}}$ & $\overline{\boldsymbol{Y}}$ & $\overline{\boldsymbol{X}}_{\mathbf{-}} \overline{\boldsymbol{Y}}$ \\
\hline Tangible & 3.23 & 4.17 & 3.56 & 4.21 & 3.23 & 4.32 & 3.34 & 4.23 & $-0 ., 89$ \\
Realibilty & 3.73 & 4.10 & 3.78 & 4.26 & 3.55 & 4.32 & 3.69 & 4.23 & -0.54 \\
Responsiveness & 3.57 & 4.00 & 3.55 & 4.17 & 3.36 & 4.18 & 3.49 & 4.12 & -0.63 \\
Assurance & 3.87 & 4.14 & 3.88 & 4.24 & 3.67 & 4.21 & 3.81 & 4.16 & -0.35 \\
Empathy & 3.67 & 4.10 & 3.66 & 4.18 & 3.51 & 4.19 & 3.68 & 4.18 & -0.5 \\
\hline \multicolumn{1}{c}{ Rata-rata } & 3.61 & 4.11 & 3.70 & 4.22 & 3.47 & 4.22 & $\mathbf{3 . 6 0}$ & $\mathbf{4 . 1 8}$ & $\mathbf{- 0 . 5 8}$ \\
\hline
\end{tabular}

Sumber : Data Primer Diolah

$$
\text { Keterangan } \begin{aligned}
\bar{X} & =\text { Rerata Kepuasan/Kinerja } \\
\bar{Y} & =\text { Rerata Kepentingan / Harapan } \\
\bar{X}_{-} \bar{Y} & =\text { Gap / Kesenjangan antara Kepuasan dan Kepentingan }
\end{aligned}
$$

Dari tabel 6 diatas, diketahui bahwa rata-rata nilai kepuasan untuk FEB adalah 3,60 sedangan kepentingan/harapan berada pada nilai 4,18 , jadi masih ada kesenjangan antara kinerja yang diharapkan dengan kinerja aktual sebesar -0,58. Apabila dimasukkan kedalam tabel tingkat kepuasan, maka angka ini berada pada kategori memuaskan (M). Kepuasan yang paling tinggi didapatkan pada dimensi Assurance dengan nilai 3,81 artinya kinerja dosen dan pegawai dalam memberikan layanan kepada seperti dosen 
kompetensi dosen pada mata kuliah yang diampunya, perlakuan yang adil tanpa pandang bulu dari dosen dan pegawai, kurikulum yang sesuai dengan kebutuhan industri saat ini, dipedomaninya SOP/ POB dengan baik untuk melayani mahasiswa, dan sebagainya.

Akan tetapi dimensi yang mendapatkan penilaian paling rendah adalah Tangible dengan nilai 3,34 hal ini berarti: pelayanan yang diberikan oleh dosen dan pegawai pada dimensi ini belum memuaskan mahasiswa seperti: ketersediaan sarana/prasarana perkuliahan (ruang belajar dengan kelengkapannya), sarana penunjang belajar (alat bantu ajar), sarana pendukung (tempat parkir, kantin, perpustakaan, toilet), dan sebagainya masih memerlukan pembenahan yang serius. Pada dimensi ini juga terjadi kesenjangan yang paling lebar yaitu nilai kepuasan 3,45 dibandingan dengan kepentingan/harapan dengan nilai 4,23 atau kesenjangannya $=-0,78$.

\section{Indeks Kepuasan Mahasiswa FEB. Unram}

Berdasarkan analisis kesenjangan seperti pada tabel 6 diatas, maka dapat diketahui Indeks Kepuasan Mahasiswa (IKM) pada masing-masing dimensi dengan rumus IKM $=\mathrm{S} /(5 \mathrm{xI})$, dimana $\mathrm{S}($ Skor) = Hasil Perkalian antara rata-rata kepentingan $(\bar{Y})$ dengan rata-rata kepuasan $(\bar{X})$. Untuk lebih lengkapnya dapat dilihat pada tabel 7 dibawah ini.

Tabel 7.

Indeks Kepuasan Mahasiswa FEB. Unram

\begin{tabular}{lccccccc}
\hline \multicolumn{1}{c}{ Dimensi } & $\bar{X}$ & $\bar{Y}$ & $\begin{array}{c}\text { Skor }= \\
(\bar{X} \mathbf{x})\end{array}$ & $\begin{array}{c}\text { IKM }= \\
\mathbf{S} /(\mathbf{5 x} \bar{Y})\end{array}$ & $\begin{array}{c}\text { Kategori } \\
\text { Kepuasan }\end{array}$ & $\begin{array}{c}\text { Kategori } \\
\text { Kualitas } \\
\text { Layanan }\end{array}$ & Peringkat \\
\hline Tangible & 3.45 & 4.23 & 14,59 & $69,03 \%$ & Puas & Baik & V \\
Realibilty & 3.69 & 4.23 & 15,61 & $73,80 \%$ & Puas & Baik & II \\
Responsiveness & 3.49 & 4.12 & 14,38 & $69,80 \%$ & Puas & Baik & IV \\
Assurance & 3.81 & 4.16 & 15,85 & $76,20 \%$ & Puas & Baik & I \\
Empathy & 3.68 & 4.18 & 15,38 & $73,59 \%$ & Puas & Baik & III \\
\hline \multicolumn{1}{c}{ Rata-rata } & $\mathbf{3 . 6 2}$ & $\mathbf{4 . 1 8}$ & $\mathbf{1 5 , 1 5}$ & $\mathbf{7 2 , 4 8 \%}$ & Puas & Baik & - \\
\hline
\end{tabular}

Sumber : Data Primer Diolah

Dari tabel 7 diketahui bahwa secara keseluruhan rata-rata nilai kepuasan untuk FEB adalah 3,62 sedangan kepentingan/harapan berada pada nilai 4,18, jadi masih terdapat kesenjangan antara kinerja aktual dengan kinerja yang diharapkan yaitu sebesar -0,56. Apabila dimasukkan kedalam tabel kategori, maka tergolong puas atau memuaskan (M).

Apabila diperhatikan secara per dimensi, maka akan terlihat dimensi Assurance yang paling tinggi skornya yaitu 15,85 dengan IKM $=76 \%$, yang masih termasuk dalam kategori kualitas layanan baik. Setelah itu Realibilty dengan skor 15,61 dan $\mathrm{IKM}=73,80 \%$. Dan yang paling rendah adalah dimensi Tangible dengan Skor $=14,59$ dan $\mathrm{IKM}=69,03 \%$.

Secara keseluruhan kepuasan mahasiswa terhadap layanan pendidikan yang dirasakannya berada pada skor 15,15 yang termasuk dalam kategori puas dengan $\mathrm{IKM}=72,48 \%$ dan termasuk dalam kualitas layanan berkategori baik. 


\section{SIMPULAN DAN SARAN}

\section{Kesimpulan}

Dari pembahasan dan analisis diatas dapat menyimpulkan hal-hal sbb.:

1. Penilaian mahasiswa terhadap rata-rata tingkat kepuasan layanan pendidikan di FEB. Unram mendapatkan skor 15,5 dengan IKM=72,48\% yang berada pada level "Memuaskan" dengan kualitas layanan berkategori "Baik".

2. Tidak terdapat kesenjangan yang lebar antara tingkat kepuasan dengan tingkat kepentingan pada ketiga jurusan yang diteliti dengan kesenjangan masing-masing 0,42 dengan IKM=73,82\% untuk jurusan Manajemen, 0,52 dengan IKM=73,98\% jurusan Akuntansi dan 0,75 dengan IKM=69,38 untuk jurusan IESP dengan kualitas layanan yang dirasakan oleh ketiga jurusan tersebut berkategori baik.

3. Tingkat kepuasan yang paling tinggi dirasakan oleh ketiga jurusan di FEB. adalah dimensi Assurance dengan nilai rata-rata= 3,87 untuk jurusan Manajemen, 3,88 untuk jurusan Akuntansi dan 3,67 untuk jurusan IESP. Sedangkan kinerja yang paling rendah yang dirasakan mahasiswa adalah pada dimensi Tangible untuk jurusan Manajemen dan IESP dengan nilai yang sama yaitu rata-rata=3,23. Sedangkan untuk jurusan Akuntansi kinerja yang paling rendah dirasakan pada dimensi Realibility dengan nilai rata-rata=3,55.

\section{Saran}

Berdasarkan analisis data dan hasil observasi dapat disarankan hal-ha sbb.:

1. Dimensi yang paling rendah mendapatkan penilaian dari mahasiswa adalah Tangible yang terdiri dari penyediaan sarana dan prasarana perkuliahan seperti: toilet yang kurang memadai dan tidak terawat, AC yang tidak terawat, musholla yang sempit, kurangnya fasilitas olah raga dan tidak tersedianya kantin yang memadai, sedangkan alat bantu ajar diperlukan perawatan dan pemeliharaan yang baik agar selalu dapat digunakan setiap saat diperlukan.

2. Selain itu perlu mendapatkan perhatian akan adanya sebagian dosen dan pegawai yang belum bisa melakukan pekerjaannya dengan baik sehingga urusan-urusan penting mahasiswa menjadi terbengkalai seperti: sulitnya mahasiswa menemui dosen pembimbing skripsi, dan ini dapat mengganggu kelulusan mahasiswa tepat waktu.

\section{REFERENSI}

Al-Alak, Basher A and Ahmad Salih Mheidi Alnaser, 2012. Assessing the Relationship Between Higher Education Service Quality Dimensions and Student Satisfaction, Australian Journal of Basic and Applied Sciences, 6(1): 156-164,

Arikunto, suharsimi. 2006.Prosedur Penelitian Suatu Pendekatan raktek Jakarta: PT Renika Cipta

Arikonto Suharsimi,. 2002. Prosedur Penelitian Suatu Pendekatan Praktek. Jakarta: Rineka Cipta.

Assail, H. 2004. Consumer Behavior: A Strategic Approach. Houghton Mifflin Company. USA.

Assauri, S. 1999. Manajemen Pemasaran. Dasar Konsep, dan Strategi. Jakarta: Rajawali Press. 
Cooper, D. R., dan P. S. Schindler. 2006. Marketing Research. Eight Edition. McGrawHill. New York

Cravens, D.W. 2006. Pemasaran Strategis, Jakarta: Erlangga.

Ghozali, I. 2001. Aplikasi Analisis Multivarate Dengan Program SPSS. Badan Penerbit Universitas Diponegoro. Semarang

Irawan d, H. 2007. 10 Prinsip Kepuasan Pelanggan. Cetakan Kedelapan PT. Elex Media Komputindo. Jakarta

Kotler, Philip \& Keller, Kevin Lane, 2016: Marketing Management, $12^{\text {th }}$ Edition, Pearson Prentice Hall, New Jersey.

Kotler, Philip. 2000. Manajemen Pemasaran, Analisis, Perencanaan, Implementasi, dan Pengendalian, Edisi Kesembilan, Jilid 1\&2. Salemba Empat: Prentice Hall.

Kotler ,Philip dan Gary Amstrong. 2004. Dasar-dasar Pemasaran. Jilid 1. Edisi kesembilan. Indeks kelompok gramedia. Jakarta

Kotler, P., dan Amstrong. 2005. Dasar-dasar Pemasaran Jilid 2. Terjemahan Alexandor Sindoro. Jakarta: Pernhallindo.

Kotler, P. and Kervin Lane Keller. 2008. Manajemen Pemasaran. Edisi Kedua Belas Jilid I \& II. PT. Indeks, PT. Mancana Jaya Cemerlang, Jakarta.

Lele, Milliand M \& Sheth, Jagdish N, 1991: The customer is key: gaining an unbeatable advantage through customer satisfaction, John Wiley \& Sons

Lovelock, C., dan J. Wirtz. 2007. Service Marketing: people, Technology, Strategy.Sixth Edition. Pearson Prentive Hall. USA

Malhotra, N. K. 2007. Marketing Research: An Applied Orientation. Pearson Prentice Hall, United States of America.

Manzoor, Hasnain (2013): Measuring Student Satisfaction in Public and Private University in Pakistan, Global Journal Of management And Business Research Interdiciplinary.

Motefakker, Niloofar (2016) : The study of the level of satisfaction of the students of faculty of social sciences with Wefare Services of Imam Khomeini International University of Qazvin, Procedia of Economics and Finance.

Rambat, Lupiyoadi, \& Ikhsan, Ridho Bramulya, 2015: Praktikum Metode Riset Bisnis, Salemba Empat, Jakarta.

Rambat, Lupiyoadi, 2013. Manajemen Pemasaran Jasa: Berbasis Kompetensi. Penerbit Salemba Empat, Jakarta

Startup, Richard, 2015: Student Satisfaction with academic services, Educational Research, Swansea.

Sigit, Soehardi, 1999 : Pengantar Metodologi Penelitian Sosial-Bisnis, Manajemen.

Yogyakarta.

Tjiptono, Fandy dan Chandra, Gregorius. 2011. Service, Quality dan Satisfaction. Yogyakarta: Penerbit Andi.

Tjiptono, Fandy dan Chandra, Gregorius. 2016 Service, Quality dan Satisfaction. Yogyakarta: Penerbit Andi. 
Widodo, Sanusi Mulyo dan Sutopo, Joko, 2018, Metode Customer Satisfaction Index (CSI) Untuk Mengetahui Pola Kepuasan Pelanggan Pada E-Commerce Model Business to Customer, Jurnal Informatika Upgris Vol 4 No.1 2018.

Yola, Melva dan Duwi Budianto: Analisis Kepuasan Konsumen Terhadap Kualitas Pelayanan Dan Harga Produk Pada Supermarket Dengan Menggunakan Metode Importance Performance Analysis (IPA). Jurnal Optimasi Sistem Industri, Vo. 12 No. 12 April 2013.

Yousapronpaiboon, Khancitpol 2014, SERVQUAL: Measuring higher education service quality in Thailand, Procedia Social and Behavioral Sciences. 